\title{
FORTY YEARS OF FAMILY LAW: A RETROSPECTIVE
}

\author{
Patrick Parkinson*
}

This article presents a thematic retrospective of the past 40 years of family law in terms of the
international landscape in developed countries. It examines three questions: First, whatever
happened to marriage? While once marriage was central to family formation, it is no longer.
Indeed, heterosexual couples have never been less interested in the idea of marriage. Secondly,
whatever happened to divorce? The nature of divorce has fundamentally changed in the last forty
years, largely as a consequence of the recognition that while intimate domestic partnerships may
come to an end, parenthood is, for the most part, indissoluble. The ties that bind parents together
remain important long after the adult relationship has ended. Thirdly, whatever happened to
parenthood? Legal parenthood has become vastly more complicated than in the mid-1970s. One
reason for this is the revolution in artificial reproduction techniques. A second reason is that
lesbian and gay couples have, in increasing numbers, sought to raise children and demanded
recognition of parental rights which are not based on genetic parenthood. These changes have had
a profound impact upon modern family law.

\section{INTRODUCTION}

Over a 40-year career (so far), Bill Atkin has made a substantial contribution to family law in New Zealand. His work in this field covers a large number of topics and, like most academic family lawyers, his interests have changed over time. What is consistent about Bill's work is its quality. With every issue he tackles, he brings careful scholarship and wise insights.

His contributions to family law also extend far beyond New Zealand. In writings for scholars in other countries, he has explained interesting and important developments in New Zealand law such as its innovative changes to the law of child protection, ${ }^{1}$ and reforms to family property law. ${ }^{2}$ Many

* Professor of Law, University of Sydney.

1 Bill Atkin "New Zealand: Let the Family Decide: The New Approach to Family Problems" (1990-1991) 29 J Fam L 387.

2 See for example Bill Atkin "New Zealand: Reflections on New Zealand's Property Reforms 'Five years on'" in Bill Atkin (ed) The International Survey of Family Law (Jordan Publishing, Bristol, 2007) 217. 
of us have learned an enormous amount from him. He has also contributed greatly to international and comparative family law scholarship through his role as the long-time Editor of the International Survey of Family Law, published on behalf of the International Society of Family Law, of which he has been an active member for much of his career.

In this article, I want to offer a retrospective on the changes in family law that Bill will have seen in the course of his career. There is little of the family law landscape which remains the same as it was 40 years ago. The changes are vast, not only in substantive law but in terms of practice, procedure and the structure of the court system. Radical change continues into the present, not least, in New Zealand, with the major developments in family law processes initiated in 2014, which have wound back the involvement of lawyers in the family justice system. ${ }^{3}$

Bill has already contributed to an article examining developments over the last half century in New Zealand law. ${ }^{4}$ In this article I provide a thematic retrospective in terms of the international landscape in developed countries, which, I hope, will place New Zealand developments within a broader perspective. I consider three developments in particular - the changes which have occurred in relation to marriage, to divorce and to parenthood.

\section{WHATEVER HAPPENED TO MARRIAGE?}

Today, one of the most difficult issues confronting legislatures and policy-makers is how to resolve the debate about whether marriage should be redefined to include same-sex couples. New Zealand has already made that change. Thus far, the Australian Parliament has resisted it. ${ }^{5}$

Yet this new interest in the status of marriage is somewhat paradoxical, for it comes at a time when heterosexual couples have never been less interested in the idea of marriage. One of the most striking changes in family life over the last 40 years has been the decline in the centrality of marriage, at least in those parts of the world that have historically been mainly Christian nations. ${ }^{6}$ This reflects a combination of two trends. The first is the decline of religious faith in many of these

3 These are summarised at Ministry of Justice "Changes to family justice" (December 2014) <www.justice.govt.nz>. See also Bill Atkin "Upheaval in the Family Court of New Zealand" (paper presented to XVth World Conference of the International Society of Family Law, Recife, Brazil, August 2014).

4 Bill Atkin and others "Fifty years of New Zealand Family Law" (2013) 25 NZULR 645.

5 In September 2012, two Bills which would have permitted marriages of same-sex couples were decisively defeated in the Federal Parliament. See further Luke Taylor "Getting Over It? The Future of Same-sex Marriage in Australia" (2013) 27 AJFL 26. The present Government has proposed a plebiscite after the election which is scheduled in 2016.

6 For an overview of trends in Australia, see Ruth Weston and Lixia Qu "Trends in Family Transitions, Forms and Functioning: Essential Issues for Policy Development and Legislation" in Alan Hayes and Daryl Higgins (eds) Families, Policy and the Law: Selected Essays on Contemporary Issues for Australia (Australian Institute of Family Studies, Melbourne, 2014) 7. 
countries, particularly in Europe. The second is the decline in adherence to Christian teaching on sex and marriage, even in those countries with still high levels of religious commitment.

Christian teaching has, in the past, provided a strong discipline in terms of sexual expression and family life. ${ }^{7}$ The sexual union, consummated, according to traditional Christian sexual ethics, on the wedding night, was an expression of a more fundamental union; a union of lives until death parted them. Similar values are to be found in other faiths also, notably Orthodox Judaism and Islam, but it was Christian teaching which shaped the family life of the nations of the western legal tradition.

In detail, there were differences between Catholic and Protestant countries. Christian teaching in the Catholic tradition offered no option of divorce - although the severity of that rule was tempered by the sophistry and flexibility of Catholic notions of nullity. In Protestant theology, there was some allowance for divorce for fault such as adultery, but there was still a strong emphasis on the idea of marriage as a sacred commitment made before a watching and all-seeing God. ${ }^{8}$ In jurisdictions such as Britain, the right to divorce was almost entirely theoretical before the mid-19th century. ${ }^{9}$

In many countries, those values no longer seem to have a great deal of influence on behaviour in terms of sex and family life. This is true of much of Europe, but not only Europe. It is true also of much of North and South America as well. In some countries of Western Europe, marriage and cohabitation have now become almost interchangeable in terms of socially accepted forms of family formation. ${ }^{10}$ In some South American countries, more people of childbearing age are living in cohabiting relationships than are married. ${ }^{11}$

Marriage remains the most common form of couple relationship within Western Europe, but the gap between marriage and cohabitation as a family form is narrowing. For example, figures from

7 See for example Andrew Cornes Divorce and Remarriage: Biblical Principles and Pastoral Practice (Mentor, Fearn, 1993).

8 Mary Ann Glendon State, Law, and Family: Family Law in Transition in the United States and Western Europe (North Holland, Amsterdam, 1977); and Roderick Phillips Putting Asunder: A History of Divorce In Western Society (Cambridge University Press, New York, 1988). See also Mary Ann Glendon Abortion and Divorce in Western Law (Harvard University Press, Cambridge (Mass), 1987).

9 Lawrence Stone Road To Divorce: England 1530-1987 (Oxford University Press, Oxford, 1990).

10 Kathleen Kiernan "The Rise of Cohabitation and Childbearing Outside Marriage in Western Europe" (2001) 15 IJLPF 1; and Anne Barlow and others Cohabitation, Marriage and the Law: Social Change and Legal Reform in the 21st Century (Hart, Oxford, 2005).

11 ChildTrends World Family Map 2014: Mapping Family Change and Child Well-being Outcomes (2014) at 16. 
2006 show that in France, 26 per cent of adults in the 18-49 age range were cohabiting, while 39 per cent were married. In Sweden, 25 per cent were cohabiting and 37 per cent were married. ${ }^{12}$

If the growth in cohabitation as a form of family formation were confined to childless couples it would not represent a major transformation in family life. Cohabitation could be seen then as a form of trial marriage or precursor to marriage. However, increasingly, cohabitation is a context for childrearing. This can be seen in the increase in ex-nuptial births. In Britain, 47.5 per cent of all births occurred outside of marriage in $2012 .{ }^{13}$ Half or more of all births are ex-nuptial in Belgium, Bulgaria, Estonia, France, Iceland, Slovenia, Norway and Sweden. The highest rate, within Europe, is in Iceland at 65 per cent of all births. ${ }^{14}$ While more than half of these exnuptial births across Europe are in cohabiting unions, there are significant variations between countries. ${ }^{15}$

A further dramatic shift is in the proportion of all births to single mothers without partners in the home. For example, in Ireland, 35 per cent of all births are outside marriage. Of these, nearly half (45 per cent) are to single mothers; that is nearly 16 per cent of all births. ${ }^{16}$ The figure is the same in Britain. ${ }^{17}$ In the United States, between 2006 and 2010, 24 per cent of first births were to women who were neither married nor cohabiting. ${ }^{18}$

The demise of marriage as the normal context for childrearing has probably had a much greater effect upon the stability of family life than any changes to the law of divorce. The evidence from many parts of the world indicates that cohabiting relationships are typically quite short term, and this is so even when there are children. ${ }^{19}$ In an Australian study, the odds of a cohabiting couple with children breaking up was more than seven times as high as a married couple who had not lived

12 At 16 .

13 Office for National Statistics Statistical Bulletin: Births in England and Wales, 2012 (10 July 2013).

14 Carl Haub "Rising Trend of Births Outside Marriage" (2013) Population Reference Bureau <www.prb.org>.

15 Haub, above n 14.

16 Haub, above n 14.

17 Office for National Statistics Statistical Bulletin: Live Births in England and Wales by Characteristics of Mother 1, 2012 (15 October 2013).

18 Gladys Martinez, Kimberly Daniels and Anjani Chandra "Fertility of Men and Women Aged 15-44 Years in the United States: National Survey of Family Growth, 2006-2010" (2012) 12(51) National Health Statistics Reports 1 at 9.

19 Kathleen Kiernan "Cohabitation in Western Europe" (1999) 96 Population Trends 25. 
together before marriage, and more than four times as high as those who had lived together but went on to marry. ${ }^{20}$

The reality is, then, that a substantial proportion of children in developed countries are born into, or as a consequence of, temporary relationships. Before those children have reached adulthood, they may well experience a number of different family constellations, with mothers forming, and later ending, other live-in relationships and giving birth to other children.

It follows that modern family law cannot now just be concerned only with the law of marriage and divorce. Nor should family laws be drafted, consciously or unconsciously, with the idea that marriage is the basis for intimate domestic relationships. As both New Zealand ${ }^{21}$ and Australia ${ }^{22}$ have long accepted, it is necessary for there to be some recognition of cohabiting relationships in the law, and to have some remedial laws to deal with the consequence of the breakdown of these relationships.

An ongoing argument now is whether to assimilate cohabitation with marriage, thereby applying the traditional marriage paradigm to cohabitation. People cohabit outside marriage for a range of different reasons. ${ }^{23}$ Some people live together with the intention of getting married. ${ }^{24}$ Others may enter a cohabiting relationship with a hope or intention on the part of at least one of them that they will marry, but the relationship does not survive long enough for this to occur. ${ }^{25}$ Others reject the idea of formal marriage entirely, ${ }^{26}$ but see themselves as being in a committed and ongoing relationship. ${ }^{27}$ For others who live in the present without necessarily seeking to plan the future, the

20 Peter Butterworth and others Factors Associated with Relationship Dissolution of Australian Families with Children (Department of Families, Housing, Community Services and Indigenous Affairs, Social Policy Research Paper 37, 2008) at 29, table 9.

21 Bill Atkin "The Legal World of Unmarried Couples: Reflections on 'De Facto Relationships' in Recent New Zealand Legislation" (2008) 39 VUWLR 793.

22 See for example Lindy Wilmott, Ben Mathews and Greg Shoebridge "De Facto Relationships Property Adjustment Law - A National Direction?" (2003) 17 AJFL 37; and Family Law Amendment (De Facto Financial and Other Measures) Act 2008 (Cth).

23 Lixia Qu "Expectations of Marriage among Cohabiting Couples" (2003) 64 Family Matters 36.

24 The Australian Bureau of Statistics reported that 42 per cent of those in a de facto marriage in 2006-2007 stated that they expected to enter into a registered marriage with their current partner: Australian Bureau of Statistics "Family Characteristics and Transitions, Australia" (2011) <www.abs.gov.au>.

25 Penelope Huang and others "He Says, She Says: Gender and Cohabitation" (2011) 32 J Fam Issues 876; and Susan Brown "Union Transitions among Cohabiters: The Significance of Relationship Assessment and Expectations" (2000) 62 J Marriage \& Fam 833.

26 For Australian evidence, see Sandra Buchler and others "The Social and Demographic Characteristics of Cohabiters in Australia: Towards a Typology of Cohabiting Couples" (2009) 82 Family Matters 22.

27 On the different meanings of commitment, see Jan Pryor and Josie Roberts "What is Commitment? How Married and Cohabiting Parents Talk About Their Relationships" (2005) 71 Family Matters 24. 
intimate partnership may just be a relationship for the time being, with the move from living apart to living together occurring mainly for pragmatic reasons such as saving on rent. ${ }^{28}$

It is far from clear that norms such as equal sharing of relationship property, a right to apply for maintenance, inheritance rights and other such financial rights associated with the traditional marriage partnership, should apply to these cohabiting relationships. ${ }^{29}$ Many are not socioeconomic partnerships of a kind that is typical for married couples. ${ }^{30}$ Australia and New Zealand have chosen the path of almost complete assimilation, but other jurisdictions, including England and Wales, have been much more cautious about applying the marriage paradigm to non-marital cohabitation. ${ }^{31}$ People need the freedom not to be treated as if they were married. There is still room for remedial law to address unconscionable outcomes or unjust enrichment as a consequence of the relationship breakdown. ${ }^{32}$

It makes sense also to allow the possibility of making provision for the maintenance of mothers beyond the provision of child support, irrespective of whether the parents ever lived together. This is a very sensible aspect of New Zealand law which has few parallels in other jurisdictions. ${ }^{33}$ There is a certain logic in this, if the basis for spousal maintenance is to compensate for the financial sacrifices involved in a caregiving role rather than as an outworking of the contractual duty of support arising from marriage.

\section{WHATEVER HAPPENED TO DIVORCE?}

At the beginning of the 21st century, American scholar Margo Melli asked this question in an article in the Wisconsin Law Review. Surveying the changes over her career as an American family

28 Scott Stanley, Galena Kline Rhoades and Howard Markman "Sliding Versus Deciding: Inertia and the Premarital Cohabitation Effect" (2006) 55 Family Relations 499; and Gordon Carmichael and Andrea Whittaker "Living Together in Australia: Qualitative Insights into a Complex Phenomenon" (2007) 13 Journal of Family Studies 202.

29 See further Patrick Parkinson "Quantifying the Homemaker Contribution in Family Property Law" (2003) 31 Fed LR 1 at $8-14$.

30 Supriya Singh and Clive Morley "Gender and Financial Accounts in Marriage" (2011) 47 Journal of Sociology 3 .

31 The Law Commission of England and Wales proposed reform, but without equating cohabitation with marriage: Law Commission Cohabitation: The Financial Consequences of Relationship Breakdown (Law Com No 307, 2007). This has not been implemented. See also Barlow and others, above n 10.

32 Patrick Parkinson "Beyond Pettkus v Becker: Quantifying Relief for Unjust Enrichment" (1993) 43 UTLJ 217.

33 Family Proceedings Act 1980, s 79. 
law professor, she commented on the magnitude of the changes since the emergence of no-fault divorce: $:^{34}$

[A]s we have begun to develop a legal structure more responsive to the consequences of divorce and the needs of children and their parents, we have changed the nature of divorce. The modern institution of divorce has become quite different from its predecessors; in particular, it differs from the "clean break" vision of divorce of the early no-fault period. Today, divorce is not the end of a relationship but a restructuring of a continuing relationship.

In similar vein, British sociologists Bren Neale and Carol Smart have observed that divorce in the 1970s "was a personal step that separated the old life from the new; the original family was effectively disbanded as parents opted for a clean break and entered into a tacit agreement not to interfere in each other's lives". ${ }^{35}$ In contrast, modern divorce has "been recast as a 'stage' (albeit a painful one) in the newly extended life course of the indelible nuclear family". ${ }^{36}$

\section{A Divorce as the End of the Family}

Divorce once meant the end of a marriage: the right to terminate a broken relationship and to begin anew with few, if any, ties to the former partner. The property was divided, and the children allocated to one parent or the other in what was termed the award of "custody". Only one parent could continue in that role after divorce, and the other was relegated to the role of a visiting parent, exercising "access", as the family lawyers of old so strangely called it.

To say that there were few ties between the former partners after divorce is not to say that there were none. In theory at least, men had continuing financial commitments through the payment of spousal maintenance. There was also an obligation on parents of children under 18 to pay maintenance for them. Women and men needed to relate also to organise the children's visits to the non-resident parent, or for him to visit them.

Yet it is a mistake to write the history of family law through the eyes of the more wealthy clients whom private lawyers see. Take spousal maintenance. The mythology of family law is that prior to no-fault divorce in the 1970s, men who were guilty of causing the marriage breakdown were very likely to have to pay maintenance to their "innocent" wives. Yet in the United States for example the figures suggest otherwise. Census data reveals that courts made awards of permanent alimony in only 9.3 per cent of the divorces between 1887 and 1906, only 15.4 per cent of divorces in 1916 and

34 Marygold S Melli "Whatever Happened to Divorce?" [2000] Wis L Rev 637 at 638.

35 Bren Neale and Carol Smart "In Whose Best Interests? Theorising Family Life Following Parental Separation or Divorce" in Shelley Day Sclater and Christine Piper (eds) Undercurrents Of Divorce (Aldershot, Ashgate, 1999) 33 at 35.

36 At 37. 
only 14.6 per cent of those in $1922 .{ }^{37}$ The level of awards seems to have changed little over the 20th century. In 1978, the percentage was 14.3 per cent. ${ }^{38}$ As American scholar Twila Perry has commented: ${ }^{39}$

[T] he reality is that the vast majority of divorced women have never been awarded alimony. Those who did receive it have not gotten much and often received awards of limited duration ... Alimony may present fascinating intellectual problems for scholars of family law, but, as an institution, it has never been widespread.

A similar position can be observed in Germany. In spite of a theoretical idea of post-marital "solidarity" which entitled divorced women to spousal support, a study published in 1985 found that only 21 per cent of men were obliged to pay maintenance by court order. ${ }^{40}$ That proportion did not change much in the ensuing years. ${ }^{41}$

Child maintenance was more common, yet orders for payment were typically modest and only made against a minority of fathers. In Britain, for example, the courts were willing to allow nonresident parents to prioritise the needs of second families over first families. ${ }^{42}$ In the United States, data from the Panel Study of Income Dynamics, which over-samples low-income households, showed that only 39 per cent of female-headed single parent households had any spousal or child support award in $1968 .{ }^{43}$ Eight years later, in 1976, only 30 per cent of single mothers actually received child support. ${ }^{44}$ One reason was that the obligation was so poorly enforced. ${ }^{45}$ In 1978 , $3,424,000$ women had child support due to them but only 64 per cent of the money due was paid. ${ }^{46}$

37 Paul Jacobsen American Marriage and Divorce (Rinehart, New York, 1959) at 126, cited in Lenore Weitzman The Divorce Revolution: The Unexpected Social and Economic Consequences for Women and Children in America (Free Press, New York, 1985) at 180.

38 Marygold S Melli "Alimony Trends" (1996) 19(2) Family Advocate 21.

39 Twila Perry "Alimony: Race, Privilege, and Dependency in the Search for Theory" (1994) 82 Geo LJ 2481 at 2503-2504.

40 Beatrice Caesar-Wolf, Dorothee Eidmann and Barbara Willenbacher "Gleichberechtigungsmodelle im neuen Scheidungsfolgerecht und deren Umsetzung in die familiengerichtliche Praxis" (1985) 6 Zeitschrift für Rechtssoziologie 16.

41 Roland Proksch Rechtstatsächliche Untersuchung zur Reform des Kindschaftsrechts (Bundesanzeiger, Köln, 2002) at 172.

42 Mavis Maclean "The Making of the Child Support Act of 1991: Policy Making at the Intersection of Law and Social Policy" (1994) 21 Journal of Law \& Society 505.

43 Anne Case, I-Fen Lin and Sara McLanahan "Explaining Trends in Child Support: Economic, Demographic and Policy Effects" (2003) 40 Demography 171 at 177.

44 Elaine Sorensen and Ariel Halpern Child Support Enforcement: How Well is it Doing? (Urban Institute, Discussion Paper 99-11, 1999) at 1. 
It follows that for a great many people and to a great extent, divorce did provide the opportunity for a fresh start, with little need to relate to the former partner. While some men retained a significant level of involvement with their children after separation, it was more common for men to drop out of children's lives or to have no more than a peripheral involvement with them. ${ }^{47}$

The changes in the last 40 years have been profound. They are most obvious in terms of parenting arrangements after separation.

\section{B The Continuing Ties of Parenthood}

Over time, there have been significant changes in the ideal of fatherhood, with a greater emphasis on emotional closeness and active involvement with the children. This has led to greater involvement in parenting in intact relationships, with a consequential impact upon fathers' attitudes towards post-separation parenting. ${ }^{48}$

The changes in family law concerning parenting after separation can be traced to the beginning of the 1980s. The history of family law reform in the last 40 years in Europe, North America and in other common law jurisdictions, such as Australia and New Zealand, has been the abandonment of the assumption that divorce could dissolve the family as well as the marriage when there are children.

Reforms began in a relatively mild and largely semantic way with the shift in the United States, in particular, from the notion of sole custody to joint legal custody. ${ }^{49}$ In Europe, the law reform process took a different form. Rather than making joint custody (in the sense of joint legal responsibility) an option, or even establishing a presumption in favour of this, many European countries made joint parental responsibility the default position in the absence of a court order to the

45 David Chambers Making Fathers Pay: The Enforcement of Child Support (University of Chicago Press, Chicago, 1979).

46 United States Census Bureau "Child Support and Alimony: 1989 Data" (2011) Child Support <www.census.gov>

47 In the United States, see Judith Seltzer "Relationships between Fathers and Children Who Live Apart: The Father's Role after Separation" (1991) 53 J Marriage \& Fam 79; Frank Furstenberg and others "The Life Course of Children of Divorce: Marital Disruption and Parental Contact" (1983) 48 Am Soc Rev 656; and Judith Seltzer and Suzanne Bianchi "Children's Contact with Absent Parents" (1988) 50 J Marriage \& Fam 663.

48 Carol Smart "Towards an Understanding of Family Change: Gender Conflict and Children's Citizenship" (2003) 17 AJFL 20.

49 Andrew Schepard "The Evolving Judicial Role in Child Custody Disputes: From Fault Finder to Conflict Manager to Differential Case Management" (2000) 22 University of Arkansas at Little Rock Law Review 395. 
contrary. ${ }^{50}$ This was the position in England and Wales, for example, following the implementation of the Children Act 1989 (UK). Both parents retained parental responsibility after divorce, and the decision about what used to be called "custody" and "access" became, not a decision about the allocation of a bundle of rights, but about such practical issues as where the child would live and how much time he or she would spend with the other parent. Australia adopted similar reforms in 1995. ${ }^{51}$ In different ways, similar ideas came into the law throughout Europe. In France, for example, the law of parenting after separation was based upon the principle of coparentalité from $1993 .{ }^{52}$

The demise of the concept of sole custody was, however, only the beginning of the transition that has occurred in the law of parenting after separation in countries which share the western legal tradition. Increasingly, legislation around the world is emphasising the importance of both parents being involved in children's lives. Whereas previously there had been a choice between the mother and the father as the custodial parent, now a spectrum of choices is on offer to the courts. In most cases, there will still be a primary custodian, a parent with whom the child lives for the majority of the time. However, the significance of that allocation to one parent or the other is not as great as it once was. Contact, visitation or access, howsoever it is described, is no longer the order a parent receives as a consolation if he or she loses the prize of custody. Fathers, in particular, are no longer to be marginalised by post-separation parenting arrangements.

This revolution in thinking about parenting after separation is reflected in New Zealand's Care of Children Act 2004, which emphasises the importance of children's continuing relationships after parental separation, not only in the nuclear family but beyond it. ${ }^{53}$ The principles relevant to children's welfare and best interests in s 5 include that "a child's care, development, and upbringing should be facilitated by ongoing consultation and co-operation between his or her parents, guardians, and any other person having a role in his or her care", 54 and that "a child should continue to have a relationship with both of his or her parents, and that a child's relationship with his or her family group, whānau, hapū, or iwi should be preserved and strengthened". ${ }^{55}$ This is a radically different understanding of divorce from its meaning 40 years ago.

50 These trends are reviewed in Patrick Parkinson Family Law and the Indissolubility of Parenthood (Cambridge University Press, New York, 2011) at ch 3.

51 Family Law Reform Act 1995.

52 Frédéric Vauvillé "Du Principe de Coparentalité" (2002) 209 Les Petites Affiches 4; Hugues Fulchiron "L' Autorité Parentale Renovée" [2002] Répertoire Du Notariat Defrénois 959.

53 See further Bill Atkin "New Zealand: Landmark Family Legislation" in Andrew Bainham (ed) The International Survey of Family Law (Jordan Publishing, Bristol, 2006) 305.

54 Section 5(c).

55 Section 5(e) 
Now, the meaning of divorce depends to a great extent upon the extent to which the nonresident parent wants to remain involved in his or her children's lives, and is prepared to insist upon that even in the face of opposition from the primary caregiver. Some fathers do still drop out. There are numerous reasons why fathers lose contact with, or disengage from their children. ${ }^{56}$ The main factors are serious conflict in the relationship with the mother, ${ }^{57}$ leading to maternal gateclosing $; 8$ repartnering and responsibilities to children in the new family; ${ }^{59}$ physical distance ${ }^{60}$ feelings of disenfranchisement by the legal system; ${ }^{61}$ and limited financial resources. ${ }^{62}$ Most of these men would want a much greater involvement in the children's lives if their circumstances were different. ${ }^{63}$

\section{Continuing Financial Ties Between Parents}

Financial obligations also survive divorce to a much greater extent than 40 years ago. The greatest revolution has been in terms of child support. Huge efforts are now made to ensure, to the greatest extent possible, that non-resident parents meet their obligations, at least if the parent can be traced and has an income or savings against which a child support liability can be enforced. Around the western world, considerable government expenditure is incurred in that effort.

This is so as much for New Zealand as elsewhere. Like Australia, New Zealand has a dedicated administrative agency to assess child support by means of a statutory formula, and to collect it using a range of enforcement measures as needed. The formula calculates child support based upon parental income, the number of children and other factors. The governmental interest in enforcing

56 For a review of the literature in the American context, see Solangel Maldonado "Beyond Economic Fatherhood: Encouraging Divorced Fathers to Parent" (2005) 153 U Pa L Rev 921 at 962-982.

57 James Dudley "Increasing our Understanding of Divorced Fathers who have Infrequent Contact with their Children" (1991) 40 Family Relations 279; and Geoffrey Greif "When Divorced Fathers Want No Contact with Their Children: A Preliminary Analysis" (1995) 23 J Divorce \& Remarriage 75.

58 Liz Trinder "Maternal Gate Closing and Gate Opening in Postdivorce Families" (2008) 29 J Fam Issues 1298.

59 Wendy Manning, Susan Stewart and Pamela Smock "The Complexity of Fathers' Parenting Responsibilities and Involvement with Nonresident Children" (2003) 24 J Fam Issues 645.

60 Dudley, above n 57; and Greif, above n 57.

61 Edward Kruk Divorce and Disengagement: Patterns of Fatherhood Within and Beyond Marriage (Fernwood, Halifax, 1993); and Sanford Braver and Diane O'Connell Divorced Dads: Shattering the Myths (Jeremy P Tarcher and Putnam, New York, 1998).

62 Bruce Smyth "Postseparation Fathering: What Does Australian Research Tell Us?" (2004) 10 J Fam Stud 20 at 30-33; and Anne Skevik "'Absent Fathers' or 'Reorganized Families'? Variations in Father-Child Contact After Parental Break-up in Norway" (2006) 54 Sociological Rev 114.

63 Patrick Parkinson and Bruce Smyth "Satisfaction and Dissatisfaction with Father-Child Contact Arrangements in Australia" (2004) 16 CFLQ 289. 
child support has transformed child support from being a private matter between parents to being a matter of considerable public interest and concern. Consequently, both the proportion of nonresident parents who are regularly paying child support, and the amounts that they are required to pay, have risen considerably in the last 40 years.

This change has been largely a response to the massive growth in the number of one-parent families, with consequent pressures on government welfare budgets. Reform has also been driven by concern for the effects of poverty on the future life-chances of children. The payment of child support when parents are living apart is an important strategy in the reduction of child poverty, ${ }^{64}$ and more generally in improving child well-being. ${ }^{65}$

The extent to which spousal maintenance continues to be awarded varies greatly from one jurisdiction to another. Levels of child support required of parents of minor children in jurisdictions such as Australia and New Zealand typically leave little capacity to pay spousal maintenance. Australia remains committed to a clean break approach. By way of contrast, spousal maintenance has experienced something of a revival in Canada in the last 20 years. ${ }^{66}$ The need for post-divorce maintenance has nonetheless declined with changes in patterns of maternal workforce participation. While pure role-divided marriages still exist, the patterns of life for the majority of mothers in western countries now is one in which the care of home and children is combined with paid work, with women moving in and out of part-time or full-time work at different stages of their lives. ${ }^{67}$

\section{WHATEVER HAPPENED TO PARENTHOOD?}

Parenthood has perhaps changed the least over the last 40 years. Whereas marriage is a legal status, and divorce is the termination of that status, parenthood is a natural status arising, for the great majority of parents, from the circumstances of conception and childbirth.

Yet natural parenthood and legal parenthood are two different things. In the modern law, natural parenthood may not be sufficient to confer legal parenthood, and legal parenthood may be conferred without natural parenthood.

64 Judi Bartfeld "Child Support and the Postdivorce Economic Well-being of Mothers, Fathers, and Children" (2000) 37 Demography 203; and Daniel Meyer and Mei-Chen Hu "A Note on the Antipoverty Effectiveness of Child Support Among Mother-only Families" (1999) 34 J Human Resources 225.

65 Laura Argys and others "The Impact of Child Support on Cognitive Outcomes of Young Children" (1998) 35 Demography 159.

66 Moge v Moge [1992] 3 SCR 813. See Nick Bala "Spousal Support Law Transformed - Fairer Treatment for Women" (1994) 11 Can Fam LQ 13; Carol Rogerson "Spousal Support After Moge" (1996) 14 Can Fam LQ 281; and Carol Rogerson and Rollie Thompson "The Canadian Experiment with Spousal Support Guidelines" (2011) 45 Fam LQ 241.

67 Catherine Hakim Work-Lifestyle Choices in the 21st Century: Preference Theory (Oxford University Press, Oxford, 2000); and Tom Oldham "Changes in the Economic Consequences of Divorces, 1958-2008" (2008) 42 Fam LQ 419. 
To some extent, at least, this has long been so. When Bill Atkin was beginning his career, legal fictions about parenthood were not entirely unknown. As a response to male infertility, children could be conceived through artificial insemination with semen provided by a donor, known as AID. The donor - the biological father - was not legally the parent, and the husband of the mother was deemed to be so in his place. The birth certificate reflected the fiction rather than the reality of fatherhood. This genteel fiction allowed the husband to pass himself off as the father, and if the sperm donor was sufficiently carefully chosen, no one, including the child, might know that biological and social parenthood were not aligned.

Adoption also was a means by which legal parenthood could be conferred in the absence of biological connection. There was a time when, like in the practice of AID, adoptive parents would not disclose to the child his or her real parentage. Of course, the circumstances of the child's birth were much more difficult to conceal from close friends and family who saw neither a pregnancy nor confinement.

Now, the idea of legal parenthood has become vastly more complicated than in the mid-1970s. One reason is the revolution in artificial reproduction techniques. Gone are the days when the identification of maternity was a matter of res ipsa loquitur. The increasingly common practice of surrogacy makes even the legal identification of maternity problematic. With new reproductive techniques, the woman who gives birth to a child may not be the genetic mother because, in many surrogacy cases, the baby develops from a fertilised egg of the commissioning parents that is implanted in her womb. Legal convention around the world still typically treats the birth mother as having the legal rights of parenthood unless and until she surrenders them. However, parental responsibility may be surrendered, and conferred on the commissioning couple, by court order in jurisdictions with legislation to this effect. ${ }^{6}$

A second reason for the transformation in legal understandings of parenthood is that lesbian and gay couples have, in increasing numbers, sought to raise children. ${ }^{69}$ This has been accompanied by legislation, in some jurisdictions, which confers parental rights on co-parents - that is, the partners of a biological mother or father in a same-sex relationship. ${ }^{70}$ In some jurisdictions, this is taken as

68 In Australia, there is now specific surrogacy legislation in each state, for example, Surrogacy Act 2010 (NSW) and Surrogacy Act 2010 (Qld).

69 Jenni Millbank Meet the Parents: A Review of the Research on Gay and Lesbian Families (Gay and Lesbian Rights Lobby (NSW), Sydney, 2001). The 2011 Census in Australia reported that there were 6,300 children living in same-sex couple families, up from 3,400 in 2001. This represents 0.1 per cent of all children in couple families. Australian Bureau of Statistics "Same-Sex Couples 4102.0" (2013) <www.abs.gov.au>.

70 In Australia, by s 60H of the Family Law Act 1975 (Cth), lesbian partners may be recognised as parents by operation of law, as long as they were in a de facto relationship at the time of conception and it was intended that both partners have parental responsibility. 
far as providing for alteration to the birth certificate to record two parents of the same gender. ${ }^{71}$ This is a quite different form of legal fiction from that which existed in the past. The recording of an infertile husband as father was an attempt to disguise the circumstances of conception and, perhaps, to hide the shame of male infertility. In the brave new world of legal parenthood, a biological impossibility is given a legal reality.

For lesbian couples, conception is itself not complex if there is a donor, such as a gay man, willing to provide his semen to facilitate conception. However, problems have arisen concerning the biological father's rights and status when the father wants a much greater role than the biological mother, and her partner, envisaged. ${ }^{72}$ It is a prosaic answer to the problem to say that the father's contested claim to contact with his child should be determined by reference to the best interests of the child. In the absence of any vitiating issues such as a known propensity to child abuse, whether the father should be allowed to see his child is likely to depend greatly on the value the judge places upon the lesbian couple's autonomy, against the potential value to the child of a relationship with the biological father. Such value conflicts cannot be easily resolved by reference to objective factors. The question therefore arises whether such parental rights and responsibilities should in future be resolved by reference to the agreement between the parties, unless there are clear indications that the best interests of the child would be served by departure from the terms of that agreement.

For male same-sex couples, of course, the route to procreation is very much harder. It necessarily involves finding a surrogate mother who will give birth to the child, whether from falling pregnant with the sperm of one of the men, or by implantation of a fertilised egg. Prohibitions on commercial surrogacy in many developed countries have been a factor in driving gay couples overseas to developing nations where regulation is limited or non-existent. This represents a new frontier for international family law, ${ }^{73}$ since the case for regulation, if not outright prohibition, is a very strong one. Poverty, natural or social infertility, and the profit motive represent a toxic combination. ${ }^{74}$ The possibilities for exploitation, coercion and baby trafficking are rife. Difficult issues can arise if either the surrogate mother or commissioning couple withdraw from the bargain after the birth of the child. These issues apply equally, of course, to the use of commercial surrogacy by infertile heterosexual couples.

71 See for example Status of Children Act 1978 (Qld), ss 19B and 19C; and A \& B v C [2014] QSC 111.

72 See for example Re Patrick (2002) 168 FLR 6 (Family Court of Australia).

73 For discussion, see for example Mary Keyes and Richard Chisholm "Commercial Surrogacy - Some Troubling Family Law Issues" (2013) 27 AJFL 105; and Jenni Millbank "Resolving the Dilemma of Legal Parentage for Australians Engaged in International Surrogacy" (2013) 27 AJFL 135.

74 John Pascoe "Intercountry Surrogacy - A new form of trafficking?" (paper presented to LegalWise second Annual International Family Law Conference, Cambodia, 19 September 2012). 


\section{CONCLUSION}

There can be little doubt that when Bill Atkin began his career, teaching family law, the picture of family life which he would have presented through the lens of legal recognition and regulation was very much simpler than it is now. The values which informed the law back then were also very different. Marriage as an institution for the raising of children has largely been replaced by a notion of marriage as an agreement which is terminable at will. Many in the population forgo the need for any formal agreement or exchange of promises at all. While the significance of marriage in the law has declined, legislatures and courts are increasingly concerned to affirm the rights and obligations that flow from parenthood. It is a matter of conjecture what the next 40 years will bring. 
